\title{
Research
}

\section{Debt-for-Nature Swaps in Action: Two Case Studies in Peru}

\author{
$\underline{\text { Catherine Kilbane Gockel }}^{1}$ and Leslie C. Gray ${ }^{2}$
}

\begin{abstract}
Debt-for-nature swaps are a major source of global funding for nature conservation and have been touted as a win-win solution to the problem of how to finance conservation. This paper examines how the United States' debt-for-nature-swap program, the Tropical Forest Conservation Act, works in the field. We provide an introduction to the technical aspects of the debt-for-nature swap mechanism, then describe how the program operates on the ground, using the United States-Peru swap as an example. We focus on two case studies that are largely representative of the Tropical Forest Conservation Act's work in Peru: 1) ProNaturaleza's project in the Pacaya Samiria National Reserve, and 2) five distinct projects centered around reducing illegal logging in and around Alto Purús National Park. We explore the range of programs financed through swaps, as well as whether debt-for-nature swap projects meet their goals of strengthening civil society and increasing local capacity. We also discuss the efficacy of debt-for-nature swap monitoring, which tends to privilege fiscal evaluations of area protected over direct conservation outcomes. Although Tropical Forest Conservation Act projects may well have conservation effects, the current methods of measuring success do not reflect the types of conservation impacts of Tropical Forest Conservation Act projects.
\end{abstract}

Key Words: Amazonia; civil society; debt-for-nature swaps; local capacity; nature conservation; nature conservation funding; Peru; program evaluation; resource management; Tropical Forest Conservation Act

\section{INTRODUCTION}

Debt-for-nature swaps are a major source of international nature conservation funding (Pearce 2007). Debt-for-nature swaps have been touted as a win-win solution to the problem of how to finance conservation in the developing world (Fuller 1989, Hamlin 1989). They emerged in the 1980s as the brainchild of Thomas Lovejoy (1984) and were considered an innovative tool to simultaneously address the problems of debt and forest degradation in debt-burdened countries. Debt-for-nature swaps have provided a mechanism for nature conservation by forgiving or canceling a portion of a developing country's debt to a creditor country. In exchange for debt cancellation, the developing country's government endows a trust fund in local currency for conservation activities in that country. Debt-fornature swap projects can help mitigate the "paper park" problem by providing resources for managing existing protected areas, largely through local partnerships aimed at improving capacity for conservation management (Brandon et al. 1998,
Schwartzman et al. 2000). According to Reilly (2006), the ultimate success of debt-for-nature swaps hinges on designing effective conservation programs and strengthening the institutions of civil society in order to implement long-term conservation programs.

The first generation of debt-for-nature swaps involved commercial debt and were initiated by large international NGOs: the World Wildlife Fund, The Nature Conservancy, and Conservation International. These NGOs purchased debt at a discounted rate on the secondary market and returned it to the indebted country in exchange for specific conservation commitments. Commercial debt-for-nature swaps have largely disappeared with the restructuring of commercial debt and have been replaced by government-to-government initiatives, although NGOs still play a role. International NGOs often have in-depth technical expertise and a history of working with in-country conservation partners. Because of the NGOs' financial contributions, the debt-for-nature swap 
mechanism allowed them to exercise considerable leverage in deciding where and how the debt-fornature swap funds were spent (Reilly 2006).

A large body of literature about debt-for-nature swaps developed in the 1990s. It focused on the theory and structure of debt swaps as a conservation tool as well as potential for international debt relief (Hrynik 1990, Korfhage 1990, Mahony 1992, Jakobeit 1996, Deacon and Murphy 1997, Lugar and Biden 1998, Moye 2001). Some early critics of debt-for-nature swaps were concerned about sovereignty issues related to transferring ownership of land to foreign (creditor) governments or organizations (Alagiri 1991, Deacon and Murphy 1997, Reilly 2006). In the case of the first debt-fornature swap in Bolivia in 1987, there was a public outcry and political crisis when the Bolivian people believed a conservation organization obtained title to the country's forestlands (Walsh 1987, Resor 2005). Despite these concerns, debt-for-nature swaps have not resulted in land transfers to foreign entities (Reilly 2006). To the contrary, debt-fornature swaps provide local currency to local NGOs to carry out local conservation projects.

Recent works have looked back at the history and evolution of the debt-for-nature swap mechanism (e.g., Resor 2005, Reilly 2006, Buckley 2009), while others have expounded upon other ways the tool might be used. For instance, Greiner and Lankester (2007) have discussed using the debt-fornature swap tool to alleviate farm debt in return for biodiversity conservation. Buckley (2009) proposed variants such as debt-for-education and debt2health exchanges. Debt-for-development is another twist on the model (Freeland and Buckley 2010), as exemplified by the Italian-Egyptian debt-fordevelopment experience in Radwan et al. (2008). Some are beginning to point to debt-for-nature swaps as a way to offset carbon emissions (e.g., van Noordwijk et al. 2008).

This paper describes how our examination of the United States' debt-for-nature swap program has worked in Peru. Peru is a diverse country with a long history of participation in debt-for-nature swaps. We provide an introduction to the technical aspects of the debt-for-nature swap mechanism, then describe how the program operates on the ground, using the U.S.-Peru swap as an example. Peru is an appropriate site for a case study of the U.S. debtfor-nature swap program, in part because it involved all the main players in debt-for-nature swaps: creditor and debtor governments, and the international NGOs (the World Wildlife Fund, The Nature Conservancy, and Conservation International). We explore several broader issues including the range of projects financed through swaps and how to improve debt-for-nature swap monitoring and evaluation. These issues include the range of programs financed through swaps, whether debtfor-nature swap projects meet their goals to strengthen civil society and increase local capacity, and the efficacy of debt-for-nature swap monitoring, which tends to privilege fiscal evaluations of area protected over direct conservation outcomes.

\section{Background information about the United States' debt swaps}

The United States has been active in debt-for-nature swaps. The United States Congress has twice passed legislation allowing some incarnation of swapping debt for nature: the Enterprise for the Americas Initiative in 1991 and the Tropical Forest Conservation Act in 1998. The Tropical Forest Conservation Act covers tropically forested areas throughout the world, and it authorizes other types of transactions in addition to swaps (debt reduction and debt buybacks). International NGOs became involved in U.S. bilateral swaps in 2001 through subsidized debt-for-nature swap transactions, where an NGO matches up to $30 \%$ of the U.S. government's contribution (Sheikh 2004). As of December 2008, the U.S. government had spent US\$109.5 million on 14 Tropical Forest Conservation Act agreements in 12 countries, thus generating US\$188.5 million in local currency for tropical forest conservation projects (Tropical Forest Conservation Act Secretariat 2009). Aside from tropical forest conservation, an important secondary goal of the Act has been to strengthen civil society in beneficiary countries (Bernau 2006, Tropical Forest Conservation Act Secretariat 2009).

Tropical Forest Conservation Act transactions have historically had little accountability in monitoring of conservation outcomes. A 2004 Office of Management and Budget Program Assessment Rating Tool (PART) review gave the Tropical Forest Conservation Act program a "results not demonstrated" rating, mainly because it lacked performance measures (Tropical Forest Conservation Act Secretariat 2006). Consequently, the U.S. Treasury helped develop an evaluation scorecard 
for the Tropical Forest Conservation Act as a first attempt to evaluate the success of the program (Tropical Forest Conservation Act Secretariat 2006). Each country's board, and the Tropical Forest Conservation Act oversight committee, is now required to report annually on steps taken to meet the performance criteria, which are mainly concerned with the efficiency asset management and grant-making processes.

The Tropical Forest Conservation Act measures success by the number of grants awarded and the land area ostensibly affected by the program (Tropical Forest Conservation Act Secretariat 2009). However, funding levels and hectares protected are imperfect measures of the Act's conservation impact. Most of the Act's funding goes to targeted projects that cannot be accurately measured in terms of hectares affected. Also, the number of hectares protected gives no indication as to the degree to which an area has been protected.

The lack of appropriate indicators of conservation success is a problem that extends far beyond the Tropical Forest Conservation Act and debt-fornature swaps, to the international conservation community. Conservation organizations spend billions of dollars and countless staff hours each year to protect biodiversity, often with unproven results. Conservation practitioners are beginning to understand the need to demonstrate results and to identify the most effective approaches for making use of limited conservation resources (Salafsky et al. 2002, Christensen 2003). In fact, many of the largest international conservation organizations have come together to form the Conservation Measures Partnership with the goals of developing better ways to design, manage, and measure conservation actions (Conservation Measures Partnership 2007). Thus far, most of the international conservation community's evaluation work has focused on countable project implementation and outputs. But biological monitoring is often prohibitively expensive, and most conservation impacts do not become measurable until well beyond the time frame of the project (Kapos et al.2008). With this paper, we hope to shed some light on the quest for better tools for evaluations and indicators for assessing the success of debt-for-nature swaps.

\section{METHODS}

This paper is the result of field research evaluating all of the Tropical Forest Conservation Act projects in Peru as of June 2007. Data were triangulated using interviewing, observation, and document analysis to test for consistency and to collect as much relevant information about each project as possible. Data for each case/project were analyzed using content analysis to identify core consistencies and to verify and illuminate emerging trends (Patton 2002).

In the United States, interviews were conducted with conservation officials at the headquarters of The Nature Conservancy, the World Wildlife Fund, and Conservation International, as well as with representatives of the U.S. Treasury and the Tropical Forest Conservation Act Secretariat in Washington, D.C., during August 2006. In Peru, interviews were conducted in Spanish with implementing organizations and beneficiary populations between September 2006 and June 2007. Most interviews were conducted in Spanish although some Andean communities required Spanish-Quechua translation. In Lima Peru, 11 interviews were conducted with officials from The Nature Conservancy, the World Wildlife Fund, Conservation International, USAID, Instituto Nacional de Recursos Naturales Natural Protected Areas, and PROFONANPE (i.e., the Tropical Forest Conservation Act's oversight committee) and attended oversight committee meetings. In the field, semistructured interviews with more than 42 NGO staff in their respective field offices in Lima, Puerto Maldonado, Sepahua, Atalaya, Satipo, Cusco, and Lambayeque. We also undertook 22 meetings with Instituto Nacional de Recursos Naturales staff, including the superintendent of Instituto Nacional de Recursos Naturales' Natural Protected Areas Department and park rangers from guard posts on the Inuya, Sepahua, Tahuamanu, and Piedras Rivers. Likewise, we met with 6 faculty members at Cayetano Heredia University and La Universidad Nacional Agraria la Molina. Informal key informant interviews were undertaken with over 50 villagers and 9 community leaders in various field sites. In the Pacaya Samiria National Reserve, we conducted a formal survey of 57 villagers, and we interviewed 4 Instituto Nacional de Recursos Naturales staff and 10 NGO staff members during May 2007. Responses were coded by content analysis to 
identify themes (see Kilbane Gockel and Gray 2009 for more detail). Other major sources of information included Tropical Forest Conservation Act documents and NGO reports, including all proposals and reports to the Tropical Forest Conservation Act oversight committee as of June 2007. Project materials such as scientific publications, educational pamphlets, videos, etc. were also reviewed.

We acknowledge several limitations to this research, not least that NGOs or local respondents may have overstated program success in order to prolong benefits. This study represents a case study of but one debt swap. Thus, we cannot be sure how debt swaps might differ in other country settings. Other debt-for-nature swap experiences should be discussed and evaluated. The authors are independent of the international and local NGOs involved in Tropical Forest Conservation Act projects.

\section{RESULTS \& DISCUSSION}

\section{The Tropical Forest Conservation Act's swap with Peru}

The 2002 Peru swap was subsidized by the World Wildlife Fund, The Nature Conservancy, and Conservation International, who each contributed US $\$ 370,000$. The U.S. government provided US\$5.5 million. Beginning in 2002, over the course of 16 years, US\$14.3 million in debt is set to be cancelled, and US\$10.6 million will be set aside over the next 12 years for conservation funding in Peru. The swap's goal is to build long-term forest conservation and sustainable forestry initiatives in Peru (Agreement between the United States of America and Peru 2002).

The Tropical Forest Conservation Act agreements selected ten areas within the already wellestablished Peruvian National System of Protected Areas to receive funding for conservation projects. ${ }^{[1]}$ Table 1 describes all of the Tropical Forest Conservation Act funded projects in Peru, listing the implementing organizations, budgets allocated, and length of each project. Together, these protected areas total more than 11 million hectares, and are some of the richest and most biodiverse lands on Earth. Jaguars (Panthera onca), scarlet macaws (Ara macao), and pink freshwater dolphins (Inia geogrensis) are only few of the many threatened species that depend on these areas for habitat (Tropical Forest Conservation Act Secretariat 2006).

How were Tropical Forest Conservation Act resources allocated in the Peru swap? We grouped Tropical Forest Conservation Act projects into nine major categories based on primary project goals, as stated in project proposals and confirmed via key informant interviews. (See Figure 1 for a visual representation of fund allocation based on each project's primary goal). Almost one-third of Tropical Forest Conservation Act funds were devoted to community resource management-all of which were concentrated in the Pacaya Samiria National Reserve. Construction of guard posts on Amazonian Rivers represented $20.5 \%$ of Tropical Forest Conservation Act expenditures, and was the primary focus of three separate Tropical Forest Conservation Act projects. Two projects were aimed at inspecting forest concessions, and together represented $12 \%$ of Tropical Forest Conservation Act expenditures. Two projects established smallscale Municipal Conservation Areas with local communities in the high Andes; together these comprised less than $8 \%$ of Tropical Forest Conservation Act expenditures.

Projects in the Amazon represented the bulk of Tropical Forest Conservation Act funding. Amazonian projects funded by the Tropical Forest Conservation Act aimed to prevent illegal resource extraction, build guard posts on river systems, fund management groups, and provide protected areas with logistical and staffing support. The Act has also funded high Andean conservation projects focused on conservation and reforestation in and around the Sacred Valley of the Incas. Projects also promoted environmental education and outreach to local communities and politicians. Another area of Tropical Forest Conservation Act funding has been the coastal desert forest, where a small protected area had been invaded by squatters, causing landuse conversion because of illegal logging for firewood and charcoal commercialization. The Tropical Forest Conservation Act funded a project to promote long-term planning and participatory management of the protected area. No Tropical Forest Conservation Act funds were dedicated to establishing new large-scale protected areas.

Funds were granted to Peruvian NGOs in local currency by PROFONANPE, a preexisting environmental trust fund (Agreement between the 
Table 1. Tropical Forest Conservation Act projects in Peru: descriptions.

\begin{tabular}{|c|c|c|c|c|c|}
\hline Project title & $\begin{array}{l}\text { Implementing } \\
\text { organization (NGO) }\end{array}$ & Region & $\begin{array}{l}\text { Project } \\
\text { funding } \\
\text { (nuevo } \\
\text { soles) }\end{array}$ & Term & Project description \\
\hline
\end{tabular}

Institutional strengthening and capacity building for indigenous participation in the conservation, control, and management of biodiversity in the Amarakaeri Communal Reserve, the communities, and the Reserve for Indigenous Peoples in Madre de Dios, Peru (Case 2)

Construction of Guard Posts in Alto Purús National Park (Case 2)

\section{Asociación para la \\ Conservación del \\ Patrimonio de}

Cutivireni (ACPC)

Forest Resource Conservation in the Sepahua River Watershed (Case 2)

Control of Illegal Forest Extraction in the Southeastern Section of Alto Purús National Park and in the Tahuamanu Forest (Case 2)

Implementation of the Appendices I and II for Wood Species for the Management Authority of CITESPeru (Case 2)

Implementation of the Appendices I and II for Wood Species for the Management Authority of CITESPeru (Case 2)

Implementation and Management of Cordillera Azul National Park

Implementation of a Children's Forest Center in Madre de Dios, Peru

Communal Reserve of Polylepis Forest in Cordillera del Vilcanota
Peruvian Association for Nature Conservation (APECO)

Asociación para la

Conservación del

Patrimonio de

Cutivireni (ACPC)

Bosques, Sociedad y

Desarrollo

Bosques, Sociedad y

Desarrollo

Bosques, Sociedad y

Desarrollo

Amazon S/. 393 453

Association for

Childhood and the

Environment

Association of Andean

Ecosystems (ECOAN)

Amazon S/. 798 905

Amazon S/. 412 895

Amazon S/. 551 878 003
Amazon S/. 618 520

Andes S/. 347 000 Amazon $\begin{aligned} & \text { S/. } 487 \\ & 536\end{aligned}$

Amazon S/. 715 846

1 year

10 months

2 years

Work with Sepahua's indebted forest concessionaires. Provide free technical assistance for Annual Operation Plans. Perform biological monitoring of the Sepahua watershed.

Help plan guard posts in the Monte Salvado Indigenous Community and on the Piedras River. Design and edit pamphlets on forest management and indigenous rights. Lobby for indigenous rights, and against mineral and petroleum extraction.

Build a guard post on the Tahuamanu River to control illegal logging in Alto Purús National Park. communities on leadership skills, territory titles, wood measuring, first aid, and plant communal nurseries.

Par

Conduct in-situ inspections of mahogany and cedar in forest concessions around Alto Purús National Park to ensure that timber is coming from concessions, and not from unauthorized areas. Develop a monitoring system and train customs personnel to recognize key species.

7 Conduct in-situ inspections of mahogany months and cedar in forest concessions around Cordillera Azul National Park to ensure that timber is coming from concessions, and not from unauthorized areas. Develop a monitoring system and train customs personnel to recognize key species.

Andes S/.350 $6 \quad$ Provide technical and logistical support months to Cordillera Azul National Park's headquarters and eight guard posts.

2 years Construct a Children's Forest Center on 50 ha of rainforest for children's environmental education.

1 year
Reforest high altitude polylepis forest in the Sacred Valley of the Incas and create a Communal Reserve/Private Conservation Area with rural Andean communities. 
Creation of Municipal Conservation Areas and Lobbying in the Machu Picchu District in the Cusco Department and the VilcabambaAmboro Conservation Corridor

Initial Habitat and Forest Structure Evaluation in the La Nube Biological Station-Bahuaja-Sonene National Park

Priorities for Pomac Forest Historical Sanctuary

Pacaya Samiria National Reserve (Case 1)

Instituto Machu Picchu (IMAPI)

Andes

S/. 266 112

1 year

Work with Andean municipalities to create two Municipal Conservation Areas. Conduct political and environmental outreach campaigns near Cusco.

\author{
Fundación Cayetano \\ Heredia \\ Amazon S/. 419 \\ 935 \\ Peruvian Foundation for Coastal S/. 325 \\ Nature Conservation \\ (ProNaturaleza) \\ desert 650 \\ forest
}

1 year

Implement a biological monitoring system using a grid methodology to evaluate the habitat, forest structure, and vegetation of the La Nube Biological Station in Bahuaja-Sonene National Park.

Peruvian Foundation for Amazon Nature Conservation (ProNaturaleza)
US $\$ 3.4$ million
14 years
1 year

Lay the groundwork for long-term planning and participatory management of Pomac forest, and create a collaborative Master Plan for the sanctuary. Train villagers to be voluntary park rangers and tourism guides.

Develop and implement sustainable resource management plans for paiche and arawana fish, side-necked turtle, and various palm species in the Pacaya Samiria National Reserve. Facilitate scientific research and implement a community-based biological monitoring system. Publish a book on ProNaturaleza's community resource management experiences. Coordinate with reserve headquarters to control illegal logging.
United States of America and Peru 2002). ${ }^{[2]}$ The swap's oversight committee was responsible for ensuring the terms of the swap were observed and for reviewing grant applications from local NGOs. There were five voting members on the oversight committee: one representative from the Peruvian government, one from the U.S. government, and one from each contributing NGO's in-country program office. PROFONANPE sat in on meetings as the secretary, without voting rights.

\section{Case studies of projects in Peru}

We focused on two case studies that are largely representative of the Tropical Forest Conservation Act's work in Peru in terms of project funding and primary project focus: ProNaturaleza's project in the Pacaya Samiria National Reserve, and an amalgamation of five distinct projects aimed at reducing illegal logging in and around Alto Purús National Park (see Table 1).

Case 1: The ProNaturaleza project in the Pacaya Samiria National Reserve-a long-term integrated conservation and development project
The Pacaya Samiria National Reserve is a 2-millionhectare flooded forest in the northeastern Peruvian Amazon. This seasonally flooded palm and arboreal forest is home to manatees (Trichechus inunguis), giant river otters (Pteronura brasiliensis), pink freshwater dolphins, and tapirs (Tapirus terrestris) (Instituto Nacional de Recursos Naturales 2000). It was originally created as a protected area in the 1940s to protect paiche fish (Arapiama gigas) and was made into a national reserve in 1982. Inhabitants included Cocama-Cocamilla indigenous groups and Ribereños, an ethnically diverse mix of migrants (Stocks 1983). Migration into the region had stressed the reserve's resources. The livelihoods of groups inhabiting this region included fishing and other activities such as agriculture, hunting, and gathering (Instituto Nacional de Recursos Naturales 2000). Legal commercialization of natural resources within the reserve was permitted through sustainable management plans. But overharvesting resulted in natural resource depletion and it increased in conflicts over natural resources (Kvist and Nebel 2001, ProNaturaleza and Ríos 2005). Paiche, the largest Amazonian fish, and side-necked river turtles (Podocnemis unifilis) were listed in Appendix II of the Convention on International 
Fig. 1. Tropical Forest Conservation Act projects in Peru: expenditures.

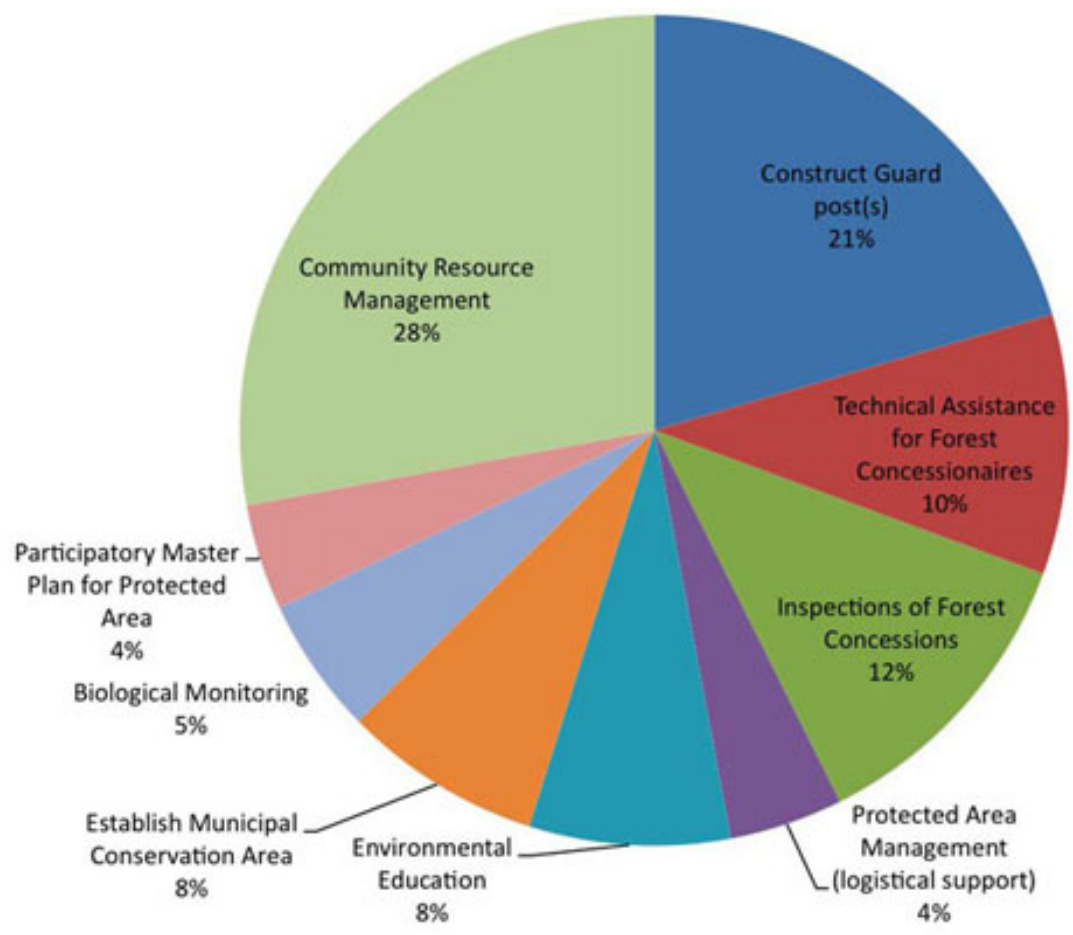

Trade in Endangered Species of Wild Fauna and Flora (CITES) (CITES Secretriat 2011) due to overharvesting. Arawana (Osteoglossum bicirrhosum) populations had been reduced because of the killing of adult males to collect fry for the international aquarium fish market (Moreau and Coomes 2006). Various palm species also suffered from deleterious harvesting practices.

The Tropical Forest Conservation Act financed a long-term integrated conservation and development project in the Pacaya Samiria National Reserve, which was implemented by The Nature Conservancy's partner organization, ProNaturaleza. The project aimed to improve management of the reserve's natural resources and enhance the wellbeing of local inhabitants (ProNaturaleza et al. 1997). The Act provided the Pacaya Samiria National Reserve project with US\$3.4 million over 12 years, which was one-third of Peru's total Tropical Forest Conservation Act funding. ProNaturaleza began working with villagers in 1994 to develop species-specific management plans that involved villager training and long-term biological monitoring. Palm management plans aimed to reduce defoliation. Other management plans involved aquatic resources (paiche and arawana fish and side-necked turtles). For paiche, plans included harvesting techniques to reduce bycatch (ProNaturaleza et al. 2006).

The results of this case study were based on surveys of 57 villagers in the Pacaya Samiria National Reserve and on interviews with Instituto Nacional de Recursos Naturales staff and NGO staff, as well as on biological monitoring data previously conducted by ProNaturaleza and local participants. Our interviews demonstrated that villagers perceived that management plans had increased species populations and improved socioeconomic well-being (Kilbane Gockel and Gray 2009). This was supported by the project's biological monitoring data. For example, ProNaturaleza was able to demonstrate significant increases in sidenecked turtle and paiche populations. Villagers gathered turtle eggs from nests on exposed beaches and relocated them to protected nests near villages. Resource management activities involved protecting turtle populations from predators and illegal extractors, and monitoring hatching turtles and 
rereleasing them into the wild. The number of eggs collected for renesting increased tenfold from 1994 to 2005. Paiche counts increased from 10 individuals in 1994 to 630 in 2003, with steady increases each year (Instituto Nacional de Recursos Naturales 2006).

The project's monitoring of socioeconomic benefits was less impressive. Socioeconomic data were collected informally, with little baseline data. Without data on actual household earnings, it was difficult to determine the socioeconomic benefits of projects. Despite the lack of rigorous socioeconomic data, villagers widely perceived that their livelihoods had improved. Our interviews indicated that $84 \%$ of participants in management groups felt that the group had improved their quality of life. Participants indicated that the project had increased local capacity to manage resources. They also cited increased household assets, group solidarity, and increased social safety nets as a result of the intervention. Participants said they felt ownership over their resource management plans and that they enjoyed the planning and training associated with the project.

Our interviews also indicated that villagers perceived important secondary effects of management activities. Villagers indicated that wild animals such as monkeys (various unspecified species), black caiman (Melanosuchus niger), giant river otter, "majaz" (Agouti paca), tapirs, dolphins, and white-lipped peccary (Tayassu pecari) were more prevalent near communities than in the past. Because these were not part of the monitoring plan, NGOs were not able to assess the recovery of nontarget species.

Integrated conservation and development projects have frequently been criticized (Oates 1999, Wunder 2001, Wilshusen et al. 2002, Christensen 2004, Terborgh 2004) because of failure to achieve either the goal of conservation or of development (Brown 2003). Does improved economic wellbeing of people around protected areas actually translate into conservation (McShane and Wells 2004, Emerton 2001)? Our interviews with villagers, as well as Instituto Nacional de Recursos Naturales and NGO staff showed that inhabitants were positive about the conservation and development benefits of the project. Project participants perceived that management plans had increased species populations and improved socioeconomic well-being. However, the ability of
ProNaturaleza to demonstrate this with monitoring data was mixed; monitoring was more focused on measuring species than on socioeconomic benefits. Although ProNaturaleza collected good information to show the conservation successes of their project, and we believe that the project did have important human development benefits, the NGO was not able to tell the development side of the story in a compelling manner. Because the project was funded for a long period and had the commitment of community members and long-term monitoring of species recovery, they were able to demonstrate conservation outcomes.

Another issue is that ProNaturaleza was unable to distinguish the results of Tropical Forest Conservation Act funding from the results associated with other sources (such as USAID and The Nature Conservancy's Parks in Peril program). From a project management perspective, this provided flexibility to use funds as-needed in the field, possibly resulting in greater conservation benefits. But this also made monitoring and evaluation more difficult, because the success or failure of the project could not be tracked by funding source.

\section{Case 2: Projects in and around Alto Purús National Park-preventing illegal mahogany logging}

Alto Purús National Park was established in 2004 and is Peru's largest protected area, covering more than 2,500,000 hectares. Alto Purús National Park is divided between the departments of Ucayali and Madre de Dios, and is surrounded mainly by forest concessions and indigenous communities. Alto Purús National Park is among the most remote and inaccessible regions of the Peruvian Amazon, and provides habitat for large predators like jaguars, pumas (Puma concolo), and anacondas (Eunectes murinus) (Instituto Nacional de Recursos Naturales 2005). The Alto Purús National Park area is also home to indigenous groups living in voluntary isolation, about whom little is known (Pitman et al. 2003). A significant portion of Peru's remaining bigleaf mahogany (Swietenia macrophylla) stands are located within Alto Purús National Park.

Despite conservation measures, ${ }^{[3]}$ illegal logging remains a major problem in Peru. The country's forestry sector is rife with corruption and informality (Smith et al. 2006). ${ }^{[4]}$ Although laws exist, enforcement is lax. Forestry personnel, police, and other officials have little incentive to report even 
the most egregious cases of illegal logging. Aside from low and unreliable pay, the state's forestry staff face high risks in the field and receive minimal institutional protection. For instance, in 2008 a local official in Madre de Dios was killed for detaining an illegal mahogany shipment (Environmental Investigation Agency 2009). Some officials have been labeled as troublemakers for reporting crimes, while others were rewarded for looking the other way (Environmental Investigation Agency 2009). Leaking information prior to field inspections is another issue, as loggers have time to hide their illegal products before brigades arrive. In some departments, mahogany quotas were established without baseline data on how many trees were in concessions (Environmental Investigation Agency 2009). There are zones in which mahogany and Spanish cedar (Cedrela odorata) have been extirpated due to overharvesting, yet falsified inventories continue to be prepared by corrupt forestry engineers, presented by concessionaires, and authorized by the government (Environmental Investigation Agency 2009).

Under Peru's forestry regime, forest concessions give the holder the right to exploit and manage forest resources within a given area generally between 5000 and 10,000 hectares (Salo and Toivonen 2009). Logging practices are required to be evaluated every 5 years to determine compliance with an approved Forest Management Plan for the concession area (Smith et al. 2006). However, there is little credibility regarding the documentation that accompanies and ostensibly guarantees the legality of forest products. Tracing the chain of custody can be nearly impossible. This enables a black market in forest transport permits to "launder" wood of illegal origin (Environmental Investigation Agency 2009). Another issue is that many concessionaires have accumulated significant debts and lack access to credit for financing forestry activities. Thus, some concessionaires have either gone bankrupt or turned to illegal logging, which gives them a competitive advantage over concessionaires who pay for forest inventories, forest management plans, permits, etc. (Karsenty et al. 2008). In some areas, the majority of wood comes from native communities instead of forest concessions. This brings up issues not only regarding the legality of the origin of the products, but also about the inhumane treatment of indigenous peoples, including forced labor and undervaluing indigenous wood (Bedoya Garland and Bedoya Silva-Santisteban 2005).
As of 2007, five of the thirteen Tropical Forest Conservation Act projects in Peru focused on reducing illegal logging in and around Alto Purús National Park. The Alto Purús projects represented approximately one-third of the debt-for-nature swap funding, and received funding for 1 or 2-year terms. Alto Purús National Park is one of the World Wildlife Fund-Peru's priority areas, and most of the Peruvian NGOs that were granted projects to work in the region had worked previously with the World Wildlife Fund.

Results draw from content analysis of data gathered from field visits; interviews with project staff, beneficiary populations, and Instituto Nacional de Recursos Naturales and other officials; and Tropical Forest Conservation Act documents. Three of the Alto Purús National Park projects focused on building guard posts around rivers. One project funded the construction of two guard posts near Alto Purús National Park through the NGO called Asociación para la Conservación del Patrimonio de Cutivireni. The Asociación built guard posts on the Inuya and Sepahua Rivers to limit access to illegal logging. The project also worked with indigenous communities along the Inuya River on leadership skills, territory titles, wood measuring, first aid, and planting communal mahogany nurseries in order to regenerate future mahogany stocks. The NGO called Bosques, Sociedad y Desarrollo built a guard post on the Tahuamanu River. This guard post bordered the reserve for indigenous peoples in voluntary isolation. The NGO called Racimos de Ungurahui and the Native Federation of the Madre de Dios River and Tributaries implemented a 2-year project to strengthen the ability of indigenous peoples in Madre de Dios to manage and control their resources. One of its main priorities was to construct a guard post in an indigenous community in the southwestern corner of Alto Purús National Park. This project also included the design of training manuals for forest and water management in indigenous communities, as well as lobbying for various timber and petroleum issues.

Another project located in the Ucayali and Madre de Dios departments (and later in the departments of San Martín and Loreto) conducted in-situ inspections of mahogany in forest concessions around Alto Purús National Park. The project's primary goal was to verify that mahogany was coming from approved forest concessions and not from inside Alto Purús National Park. This project created a methodology to verify mahogany 
populations, established baseline data of Peru's mahogany and Spanish cedar populations, and verified the Annual Operation Plans of forest concessions. In addition, the project aimed to strengthen the capacity of Peru's CITES Management Authority to implement a control system in the mahogany chain of custody. Training customs/immigration personnel to recognize valuable wood species was a secondary strategy. This project was the first mahogany/CITES verification of Annual Operation Plans with established methodology, logistics, and teams. The project was implemented by the NGO called Bosques, Sociedad y Desarrollo, in close coordination with Instituto Nacional de Recursos Naturales (the CITES Management Authority for Peru) and La Universidad Nacional Agraria la Molina (the CITES Scientific Authority for Peru). Verification methodology consisted of inspecting a radius of 500 meters around seed trees according to a selection matrix. Only trees that had been correctly georeferenced could be verified by this methodology.

The final Alto Purús National Park project worked with the indigenous community in the remote Amazonian town of Sepahua. Sepahua's forest concessionaires were heavily in debt, mainly because they were unable to pay the yearly fees for their forest concessions. As part of a 2-year project, the Asociación para la Conservación del Patrimonio de Cutivireni worked with Sepahua's most indebted concessionaires and provided technical expertise to assist concessionaires in keeping their forest concessions economically viable. A major goal of this support was to prevent concessionaires from becoming discouraged and resorting to illegal logging inside Alto Purús National Park. The Asociación assisted concessionaires by completing their Annual Operation Plans, which are costly to prepare and require in-depth forest inventories. The Asociación also partnered with the Ministry of Health and the City of Sepahua to train concessionaires in basic first aid, and it conducted baseline biological monitoring of the Sepahua watershed.

Together, these five projects represent a significant effort to assert some order in the Alto Purús region. The guard posts aimed to restrict access of illegal loggers to the Park's mahogany stores. The in-situ mahogany inspections asserted a state presence in forest concessions. Inspections revealed that a shocking percentage of concessionaires falsereported their mahogany stores. For example, field verifications determined that five forest concessions in Madre de Dios did not produce any mahogany, but nevertheless mobilized and commercialized it. Accordingly, authorities were taking actions to suspend the mobilization of timber coming from errant concessions. A country-wide baseline of mahogany stores was an important outcome of funding by the Tropical Forest Conservation Act and a critical first step in controlling illegal logging.

The Tropical Forest Conservation Act's projects in Alto Purús National Park helped build local capacity for managing resources. They trained local people, gave small Peruvian NGOs valuable field experience, and increased local capacity in remote regions of Peru. For example, the Asociación para la Conservación del Patrimonio de Cutivireni helped empower recently westernized indigenous communities by training them in basic forestry practices and helping them georeference their territorial boundaries (to avoid being taken advantage by unscrupulous loggers). The Asociación and Bosques, Sociedad y Desarrollo's projects trained forest guards to staff guard posts. The Federación Nativa de Madre de Dios's project was an exciting and rare opportunity for an Amazonian indigenous group to manage a grant. Bosques, Sociedad y Desarrollo's CITES projects trained customs officials in Lima to recognize mahogany so that it could not be exported under another name. NGO staff gained valuable experience - both in the field and with international donor relations.

The short funding cycles of most projects and limited engagement with the oversight committee limited the Tropical Forest Conservation Act's ability to build the capacity of the nonprofit sector in Peru. In contrast, ProNaturaleza gained valuable experience from being The Nature Conservancy's long-term in-country partner. This study affirmed that Alto Purús National Park projects were successful from a fiscal standpoint-grants were implemented and project activities were carried out. But the conservation outcomes of these projects were less clear. There was no long-term biological monitoring scheme nor formal evaluation. In addition, guard posts run the risk of being left vacant after short-term grants end. 


\section{RECOMMENDATIONS}

\section{Monitoring and evaluation}

By their very nature, Tropical Forest Conservation Act swaps and their individual projects are cumbersome to evaluate. Projects cover a variety of spatial and temporal scales, and have diverse goals and activities. This means that extensive monitoring and evaluation are not always appropriate. For example, the primary threat in Alto Purús National Park was from illegal logging. The land has already been declared a national park, but the local authority could not manage the area. Thus, the five projects in and around Alto Purús National Park were right to allocate almost all of their resources toward imposing order in this remote territory. Because the threat was so clearly identified, projects were effective in spending most of their resources taking action. It would not have made sense to spend vast amounts of resources on evaluation, although project managers might do well to periodically obtain satellite imagery of the area to track whether illegal roads are being built into the park (example based on Salzer and Salafsky 2006).

The amount of money awarded is currently the only indicator that evaluators and program officers can use for across-the-board comparisons of and within Tropical Forest Conservation Act swaps. But at the program level, the Tropical Forest Conservation Act should be able to demonstrate results. We discuss two approaches that could be implemented in order to gauge the success of the Act. The first approach would involve an on-the-ground impact evaluation of a single country's Tropical Forest Conservation Act swap. This would serve as a barometer of the Tropical Forest Conservation Act as a whole, and it would provide a foundation for future studies of Tropical Forest Conservation Act projects. Within a country, each Tropical Forest Conservation Act project (or series of projects) could be evaluated individually. Proving the impacts of the Act would require a formal (i.e., experimental or quasiexperimental) evaluation design, including baselines or matched control groups. However, formal evaluations are both time-consuming and costly (Campbell et al. 1966, Taylor-Powell et al. 1996, Weiss 1998). Given the modest budgets and time frames of most projects, it might not be appropriate to carry out impact evaluations for each project. Conservationists thus need better tools to evaluate and analyze the effectiveness of projects when formal evaluation is not practical (Green 2002).
Another approach might be a monitoring effort that focuses on intermediate or "key" outcomes that herald changes in threat or biological status, such as the Cambridge Conservation Forum's project on harmonizing approaches to measure conservation success (Kapos et al. 2008). ${ }^{[5]}$ For example, a key outcome for livelihood-related projects would be the abandonment of detrimental practices by the target population, while for policy interventions it would be the implementation of the policies or legislation promoted. For education and awarenessraising projects, the key outcome would be a change in behavior by the target audience (Kapos et al. 2008). This type of tool could help address the major constraints to evaluating conservation success: unclear objectives, ineffective information management, the long time frames of conservation outcomes, scarcity of resources for evaluation, and lack of incentives for evaluation (Kapos et al. 2008), many of which are also issues with the Tropical Forest Conservation Act. This sort of tool would serve mainly as a form of self-assessment, assuming that project staff are the best-qualified and have the evidence base to respond to the questionnaire.

\section{Civil society}

One of the oft-stated goals of the Tropical Forest Conservation Act has been to strengthen civil society and local capacity for monitoring and managing environmental resources (Bernau 2006, Greiner and Lankester 2007, Tropical Forest Conservation Act Secretariat 2009). Accordingly, we recommend that the Tropical Forest Conservation Act develop a mechanism for improving in-country capacity. Based on the disconnect we perceived between NGO reports and field visits to project sites, Tropical Forest Conservation Act NGOs seem to be doing impressive works with small budgets, yet seem unable to communicate that to decision-makers. Through conversations with oversight committee staff and local NGO staff, as well as through a review of Tropical Forest Conservation Act progress reports, we believe that the Act's implementing NGOs would benefit from training in nonprofit administration. For example, Tropical Forest Conservation Act oversight committee organizations could take turns offering a series of workshops on grant management, memo/report writing, performance measurement, etc. 


\section{Administration}

Based on our interviews with oversight committee members and observations of their meetings, it seemed problematic that so many parties were involved in the swap's administration. On the one hand, international NGO representatives on the oversight committee were in-country experts. On the other hand, they did not always have the necessary time to devote to overseeing Tropical Forest Conservation Act projects (they were busy managing operations for their own NGOs). This often precluded them from designating sufficient time and energy to Tropical Forest Conservation Act oversight. Another drawback of having such a large group of decision-makers was the lack of overall accountability, since no one person or organization was responsible for the success or monitoring of projects. For instance, The Nature Conservancy, the World Wildlife Fund, and Conservation International are all members of the Conservation Measures Partnership and are leaders in developing conservation audits and impact evaluations. Yet no single NGO took the lead in the case of Tropical Forest Conservation Act projects in Peru.

Short-term grant cycles of 1 or 2 years were not always sufficient for projects to get established, gain the support of local people, accomplish conservation goals, and demonstrate impact. Furthermore, many Tropical Forest Conservation Act projects were conducted in remote areas of the Amazon, which increased both time and logistical complications. Another issue is that some projects were envisioned as pilot projects, or they were designed to raise local environmental awareness, and thus prepare local communities for future conservation projects. But because the oversight committee was slow to approve follow-up efforts, these projects lost momentum in the field. Our interviews indicate that rural communities did not understand short-term grant cycles, and were sometimes disillusioned when project benefits failed to materialize. Longer grant cycles of 3 to 5 years would provide more continuity in the field.

\section{CONCLUSION}

Worldwide, debt-for-nature swaps have been and continue to be a major source of funding for nature conservation. The United States has been particularly active in debt-for-nature swaps. In two case studies of debt-for-nature swap projects in Peru, we examined some of the goals of these swaps, including increasing the efficacy of debt-for-nature swap monitoring and accountability, building local capacity, and improving swap administration. Although Tropical Forest Conservation Act projects probably have effects on nature conservation, debtfor-nature swap projects largely do not measure them in ways that can demonstrate impact or be communicated to the public. The current methods of measuring success-monies awarded and hectares protected-do not reflect the types of conservation impacts of projects. The Tropical Forest Conservation Act might consider using a key outcomes evaluation approach to help identify factors that contribute to conservation success. Furthermore, swaps are increasing local capacity, but that is not being communicated back to funders. Finally, improving swap administration, both in terms of oversight and continuity, would go a long way in improving conservation outcomes.

Responses to this article can be read online at: http://www.ecologyandsociety.org/voll6/iss3/art13/ responses/

\section{Acknowledgments:}

This study was funded by The Fulbright Program and the Environmental Studies Institute at Santa Clara University, California. Many thanks to the Tropical Forest Conservation Act Secretariat, the World Wildlife Fund, Conservation International, The Nature Conservancy, and the many NGO staff who facilitated field visits. We would also like to thank Ryan Gockel for his insight.

\section{LITERATURE CITED}

Agreement between the United States of America and Peru, Agreement signed at Washington June 26, 2002: Agreement between the Government of the United States of America and the Government of the Republic of Peru regarding a debt-for-natureswap. Washington, D.C. DC: 247005-1 GUSAGOP Debt Agreement 005b. Treaties and other International Acts Series 02-716. [online] URL: http://www.state.gov/documents/organization/151294. pdf. 
Alagiri, P. 1991. Give us sovereignty or give us debt: debtor countries' perspective on debt-for-nature swaps. American University Law Review 41:485-516.

Bedoya Garland, E. and A. Bedoya SilvaSantisteban. 2005. Trabajo forzoso en la extraction de la Madera en la Amazonia peruana. Documento de Trabajo $\mathrm{N}^{\mathrm{o}}$ 193, Oficina Internacional del Trabajo/Oficina Subregional para los Paises Andinos, Lima, Peru. [online] URL: http://www.ilo. org/wcmsp5/groups/public/---ed norm/---declaration/ documents/publication/wcms 082056.pdf.

Bernau, B. M. 2006. Help for hotspots: NGO participation in the preservation of worldwide biodiversity. Indiana Journal of Global Legal Studies 13(2):617-643. http://dx.doi.org/10.1353/gl $\underline{\text { s.2006.0011 }}$

Brandon, K., K. H. Redford, and S. E. Sanderson. 1998. Parks in peril: people, politics, and protected areas. Island Press, Washington, D.C., USA.

Brown, K. 2003. Integrating conservation and development: a case of institutional misfit. Frontiers in Ecology and the Environment 1 (9):479-487. http://dx.doi.org/10.1890/1540-9295(2003) 001[0479:ICADAC]2.0.CO;2

Buckley, R. 2009. Debt-for-development exchanges: the origins of a financial technique. The Law and Development Review 2(1):51-76. http://dx.doi.org/1 $\underline{0.2202 / 1943-3867.1027}$

Campbell, J .T., J. C. Stanley, and N. L. Gage. 1966. Experimental and quasi-experimental research designs. Rand McNally, Chicago, Illinois, USA

Christensen, J. 2003. Auditing conservation in an age of accountability. Conservation in Practice. [online] URL: http://onlinelibrary.wiley.com/doi/1 0.1111/cbp.2003.4.issue-3/issuetoc.

Christensen, J. 2004. Win-win illusions. Over the past two decades, efforts to heal the rift between poor people and protected areas have foundered. So what next? Conservation in Practice 5(1):12-19. http://dx.doi.org/10.1111/j.1526-4629.2004.tb00079. $\underline{x}$

CITES Secretariat. 2011. Appendices I, II, and III - Convention on International Trade in Endangered
Species of Wild Fauna and Flora (CITES). Geneva, Switzerland. [online] URL: http://www.cites.org/eng/ app/appendices.shtml.

Conservation Measures Partnership. 2007. Open standards for the practice of conservation, version 2.0, October 2007. [online] URL: http://www.cons ervationmeasures.org/wp-content/uploads/2010/04/ CMP Open Standards Version 2.0.pdf.

Deacon, R. T., and P. Murphy. 1997. The structure of an environmental transaction: the debt-for-nature swap. Land Economics 73(1):1-24. http://dx.doi.or $\mathrm{g} / 10.2307 / 3147074$

Emerton, L. 2001. The nature of benefits and the benefits of nature: why wildlife conservation has not economically benefited communities in Africa. Pages 208-226 in D. Hulme and M. Murphee, editors. African wildlife and livelihoods: the promise and performance of community conservation. James Currey, Oxford, UK.

Environmental Investigation Agency. 2009. Civil society perceptions and recommendations-Peru's forest sector: ready for the new international landscape? US-Peru FTA, REDD, CITES, Lacey Act and similar laws. EIA, Washington, D.C., USA. and London, UK. [online] URL: http://www.eia-gl obal.org/PDF/Report--Peru--Forest--May10--ENG. pdf.

Freeland, S., and R. P. Buckley. 2010. Debt-fordevelopment exchanges: using external debt to mitigate environmental damage in developing countries. West Northwest Journal of Environmental Law Winter 2010(16):77-101.

Fuller, K. S. 1989. Debt-for-nature swaps. Environmental Science \& Technology 23(12): 1450-1451. http://dx.doi.org/10.1021/es00070a600

Green, R.E. 2002. Diagnosing causes of population declines and selecting remedial actions. Pages 139156 in K. Norris and D. J. Pain, editors. Conserving bird biodiversity: general principles and their application. Cambridge University Press, Cambridge, UK. http://dx.doi.org/10.1017/CBO9780511606304.008

Greiner, R., and A. Lankester. 2007. Supporting onfarm biodiversity conservation through debt-forconservation swaps: concept and critique. Land Use 
Policy 24:458-471. http://dx.doi.org/10.1016/j.land usepol.2006.07.001

Hamlin, T. B. 1989. Debt-for-nature swaps: a new strategy for protecting environmental interests in developing nations. Ecology Law Quarterly 16:1065-1089.

Hrynik, T. J. 1990. Debt-for-nature swaps: effective but not enforceable. Case Western Reserve Journal of International Law 22:141-63.

Instituto Nacional de Recursos Naturales. 2000. Plan maestro de la Reserva Nacional Pacaya Samiria. INRENA, Lima, Peru.

Instituto Nacional de Recursos Naturales. 2005. Parque Nacional Alto Purús plan maestro 2005-2010. INRENA, Lima, Peru.

Instituto Nacional de Recursos Naturales. 2006. Proceso de involucramiento de pobladores locales en conservación y manejo de recursos naturales y turismo dentro de la Reserva Nacional Pacaya Samiria. Instituto Nacional de Recursos Naturales (INRENA), Lima, Peru.

Jakobeit, C. 1996. Nonstate actors leading the way: debt-for-nature swaps. Pages 127-166 in R. O. Keohane and M. A. Levy, editors. Institutions for Environmental Aid: Pitfalls and Promise. MIT Press, Cambridge, Massachusetts, USA.

Kapos, V., A. Balmford, R. Aveling, P. Bubb, P. Carey, A. Entwistle, J. Hopkins, T. Mulliken, R. Safford, A. Stattersfield, M. Walpole, and A. Manica. 2008. Calibrating conservation: new tools for measuring success. Conservation Letters 1:155164. http://dx.doi.org/10.1111/j.1755-263X.2008.00025. $\underline{\mathrm{x}}$

Karsenty, A., I. G. Drigo, M. G. Piketty, and B. Singer. 2008. Regulating industrial forest concessions in Central Africa and South America. Forest Ecology and Management 256:1498-1508. http://dx.doi.org/10.1016/j.foreco.2008.07.001

Kilbane Gockel, C., and L. C. Gray. 2009. Integrating conservation and development in the Peruvian Amazon. Ecology and Society 14(2):11. [online] URL: http://www.ecologyandsociety.org/vol14/ iss2/art11/.
Korfhage, D. 1990. Debt-for-nature swaps: economic benefit and environmental soundness. Harvard International Review 12(3):45-49.

Kvist, L. P. and G. Nebel. 2001. A review of Peruvian flood plain forests: ecosystems, inhabitants and resource use. Forest Ecology and Management 150(1-2):3-26. http://dx.doi.org/10.1 $\underline{016 / \mathrm{S} 0378-1127(00) 00679-4}$

Lovejoy, T. E. 1984. Aid debtor nations' ecology. The New York Times, 4 October 1984 (A31).

Lugar, R., and J. R. Biden, Jr. 1998. Swapping debt for nature. Christian Science Monitor 90(176). [online] URL: http://www.csmonitor.com/1998/08 05/080598.opin.opin.2.html.

Mahony, R. 1992. Debt-for-nature swaps: who really benefits? The Ecologist 22(3):97-103.

McShane, T. O., and M. P. Wells. 2004. Getting biodiversity projects to work: towards more effective conservation and development. Columbia University Press, New York, New York, USA.

Moreau, M. A., and O. T. Coomes. 2006. Potential threat of the international aquarium fish trade to silver arawana Osteoglossum bicirrhosum in the Peruvian Amazon. Oryx 40(2):152-160. http://dx.d oi.org/10.1017/S0030605306000603

Moye, M. 2001. Overview of debt conversion. Publication 4. Debt Relief International Ltd., London, UK.

Oates, J. F. 1999. Myth and reality in the rainforest: how conservation strategies are failing in West Africa. University of California Press, Berkeley, California, USA.

Patton, M. Q. 2002. Qualitative research and evaluation methods. Sage Publications, Inc. California, USA.

Pearce, D. 2007. Do we really care about biodiversity? Environmental and Resource Economics 37:313-333.

Pitman, R. L., N. Pitman, and P. Álvarez. 2003. Alto Purús: biodiversidad, conservación y manejo. Duke 
Center For Tropical Conservation, Lima, Peru. [online] URL: http://web.duke.edu/ mrpl/cps001/a $\underline{\text { lto purus/altopurusbook.html. }}$.

ProNaturaleza, and G. R. Ríos. 2005. Plan de manejo de alevinos de Osteoglussum bicirrhosum "arawana" en la cocha El Dorado-Reserva Nacional Pacaya Samiria. Organización de Pescadores y Procesadores Artesanales (OSPPA) Yacu Tayta. ProNaturaleza, Iquitos, Peru.

ProNaturaleza, G. R. Ríos, N. Noriega, and OSPPAUPC Yacu Tayta. 2006. Plan de manejo de Arapaima gigas "paiche" en la cocha el Dorado, Cuenca Yanayacu Pucate-RNPS. ProNaturaleza, Iquitos, Peru.

ProNaturaleza, The Nature Conservancy, and USAID. 1997. Informe final de ejecución, resultados y logros del proyecto: 'empleo y uso sostenible de recursos en la Reserva Nacional Pacaya-Samiria.'ProNaturaleza, Iquitos, Peru.

Radwan, S., S. Kamel, and N. El Oraby. 2008. Partners for development: the experience of the Italian-Egyptian debt swap program (2001-2008). [online] URL: http://www.utlcairo.org/stampa/Final\% 20study\%20IEDS.pdf

Reilly, W. K. 2006. Using international finance to further conservation: the first 15 years of debt-fornature swaps. Pages 197-214 in C. Jochnick and F. A. Preston, editors. Sovereign debt at the crossroads: challenges and proposals for resolving the third world debt crisis. Oxford University Press, New York, USA.

Resor, J. P. 2005. Debt-for-nature swaps: a decade of experience and new directions for the future. WWF-United States and FAO. [online] URL: http ://www.fao.org/docrep/w3247e/w3247e06.htm

Salafsky, N., R. Margoluis, K. H. Redford, and J. G. Robinson. 2002. Improving the practice of conservation: a conceptual framework and research agenda for conservation science. Conservation Biology 16:1469-1479. http://dx.doi.org/10.1046/j. 1523-1739.2002.01232.X

Salo, M., and T. Toivonen. 2009. Tropical timber rush in Peruvian Amazonia: spatial allocation of forest concessions in uninventoried frontier. Environmental Management 44:609-623. http://dx. doi.org/10.1007/s00267-009-9343-3
Salzer, D., and N. Salafsky. 2006. Allocating resources between taking action, assessing status, and measuring effectiveness of conservation actions. Natural Areas Journal 26(3):310-316. http ://dx.doi.org/10.3375/0885-8608(2006)26[310:ARBTAA] 2.0.CO;2

Schwartzman, S., A Moreira, and D. Nepstad. 2000. Rethinking tropical forest conservation: perils in parks. Conservation Biology 14(5):1351-1357. htt p://dx.doi.org/10.1046/j.1523-1739.2000.99329.x

Sheikh, P. A. 2004. Debt-for-nature initiatives and the Tropical Forest Conservation Act: status and implementation. CRS Report for Congress. Updated September 29, 2004.

Smith, J., V. Colan, C. Sabogal, and L. Snook. 2006. Why policy reforms fail to improve logging practices: the role of governance and norms in Peru. Forest Policy and Economics 8:458-469. http://dx. doi.org/10.1016/j.forpol.2005.08.001

Stocks, A. 1983. Native enclaves in the Upper Amazon: a case of regional non-integration. Ethnohistory 30(2):77-92. http://dx.doi.org/10.230 7/481242

Taylor-Powell, E., S. Steele, and M. Douglah. 1996. Planning a program evaluation. G3658-1. Program Development and Evaluation, University of Wisconsin-Extension, Madison, Wisconsin, USA. [online] URL: http://learningstore.uwex.edu/assets/ pdfs/G3658-1.PDF.

Terborgh, J. 2004. Requiem for nature. Island Press, Washington, D.C., USA.

Tropical Forest Conservation Act Secretariat. 2006. Operation of the Enterprise for the Americas Initiative and the Tropical Forest Conservation Act: Annual Report to Congress. USAID, Washington, D.C., USA.

Tropical Forest Conservation Act Secretariat. 2009. Operation of the Enterprise for the Americas Initiative and the Tropical Forest Conservation Act: Annual Report to Congress. USAID, Washington, D.C., USA.

Van Noordwijk, M., H. Purnomo, L. Peskett, and B. Setiono. 2008. Reducing emissions from 
deforestation and forest degradation (REDD) in Indonesia: options and challenges for fair and efficient payment distribution mechanisms. Working paper 81. World Agroforestry Centre (ICRAF), Bogor, Indonesia. http://dx.doi.org/10.57 16/WP15955.PDF

Walsh, J. 1987. Bolivia swaps debt for conservation: purchase of portion of debt at discount by U.S. group permits creation of conservation buffer zone for reserve. Science 237:596. http://dx.doi.org/10.1126/ science.237.4815.596

Weiss, C. H. 1998. Evaluation. Prentice Hall, Upper Saddle River, New Jersey, USA.

Wilshusen, P. R., S. R. Brechin, C. L. Fortwangler, and P. C. West. 2002. Reinventing a square wheel: critique of a resurgent "protection paradigm" in international biodiversity conservation. Society and Natural Resources 15(1):17-40.

Wunder, S. 2001. Poverty alleviation and tropical forests-what scope for synergies? World Development 29(11):1817-1833. http://dx.doi.org/1 $\underline{0.1016 / \mathrm{S} 0305-750 \mathrm{X}(01) 00070-5}$

${ }^{[1]}$ The ten designated areas were the Pacaya Samiria National Reserve, Alto Purús Reserved Zone, Manu National Park, Manu Reserved Zone, Apurimac Reserved Zone, Machu Picchu Historical Sanctuary, Bahuaja Sonene National Park, Tambopata-Candamo Reserved Zone, Amarakaeri Reserved Zone, and Cordillera Azul National Park. [2] PROFONANPE was established by the Government of Peru in 1992 to administer and manage the National Trust Fund for Peru's Protected Areas, which is composed mainly of Global Environmental Facility seed capital and donations of bilateral debt. PROFONANPE is a private nonprofit organization whose board of directors hails from the public, private, and nongovernmental sectors.

${ }^{[3]}$ In an effort to stem the illegal logging of Peruvian mahogany, the UN Convention on International Trade in Endangered Species (CITES) voted for stricter controls on mahogany exports in 2002. Mahogany became a CITES Appendix II species, meaning that trade of the species must be controlled to avoid harvests that are detrimental to the species and to ensure that wood is acquired through legal means (CITES Secretariat 2011).

[4] See Environmental Investigation Agency 2009 for an excellent overview of Peru's forestry sector. [5] The Cambridge Conservation Forum's work builds upon the Conservation Measures Partnership's Open Standards for the Practice of Conservation, which is a set of project cycle or adaptive management standards (Conservation Measures Partnership 2007). See www.cambridgeconservatio nforum.org.uk/measures outputs.htm . 